\title{
ANALISIS MINAT BELAJAR SISWA SMP TERPADU COKROAMINOTO DENGAN MENGGUNAKAN MEDIA ICT BERBASIS VBA EXCEL PADA MATERI KPK DAN FPB
}

\author{
Wina Nur Alifah Suherman', Susan Amelia', Siti Chotimah ${ }^{3}$ \\ 1,2,3 IKIP Siliwangi, Jl. Terusan Jendral Sudirman, Cimah, Jawa Barat, Indonesia \\ winaalifah02@gmail.com
}

\begin{abstract}
This research has a purpose to analyze student interest in learning with the media ICT based VBA excel on theory KPK and FPB which is conducted method using method descriptive qualitative This research was conducted at Cokoaminoto Integrated Middle School in West Bandung Regency with a population of 20 students of class VII. The research instruments provided were Questionnaire interest in learning consists of 20 questions with 5 indicators related to ICT media -based Excel VBA and provided 4 student answer choices namely strongly agree (SS), agree (S), disagree (TS) and strongly disagree (STS. Based on the results of the analysis of the data obtained. namely, with indicators of feeling happy reaching $74.1 \%$, indicators of student interest reaching $74.5 \%$, indicators of student involvement reaching $72.8 \%$, indicators of diligence in learning reaching $66.7 \%$, indicators of perseverance and discipline reaching $73.7 \%$. Then it can be concluded that by using ICT medi a -based Excel VBA can influence student learning interest in ongoing learning.
\end{abstract}

Keywoards: Readabillity study, KPK and FPB, ICT media -based Excel VBA

\begin{abstract}
Abstrak
Penelitian ini memiliki tujuan untuk menganalisis minat belajar siswa dengan media ICT berbasis VBA excel pada materi KPK dan FPB. Metode yang dilakukan menggunakan metode Deskriptif Kualitatif. Penelitian ini dilakukan di SMP Terpadu Cokoaminoto di Kabupaten Bandung Barat dengan jumlah populasi 20 siswa kelas VII. Intrumen penelitian yang berikan berupa Angket minat belajar terdiri dari 20 pertanyaan dengan 5 indikator yang ada kaitannya dengan media ICT berbasis VBA Excel dan disediakan 4 pilihan jawaban siswa yaitu sangat setuju (SS), setuju (S), tidak setuju (TS) dan sangat tidak setuju (STS). Berdasarkan dari hasil analisis data yang diperoleh yaitu dengan indikator perasaan senang mencapai 74,1\%, indikator ketertarikan siswa mencapai 74,5\%, indikator keterlibatan siswa mencapai $72,8 \%$, indikator rajin dalam belajar mencapai 66,7\%, indikator tekun dan disiplin mencapai 73,7\%. Maka dapat disimpulkan bahwa dengan menggunakan media ICT berbasis VBA Excel dapat mempengaruhi minat belajar siswa dalam pembelajaran yang sedang berlangsung.
\end{abstract}

Kata Kunci:Minat Belajar, KPK dan FPB, Media ICT berbasis VBA Excel

Matematika merupakan suatu ilmu universal yang mendasari segala sesuatu tentang hal yang mendasari suatu perkembangan teknologi saat ini, perkembangan teknologi yang semakin pesat (Haerini, 2019) memerlukan suatu penguasaan ilmu matematika yang kuat serta harus di tanami bekal yang sejak dini, mulai dari sekolah dasar sampai dengan perguruan tinggi, matematika juga memiliki suatu hal yang sangat penting dalam bidang kedisiplinan ilmu dan juga berfungsi untuk memajukan perkembangan daya pikir manusia (Akbar, 2018; Al Ayubi, 2018; Bernard, 2019; Hidayat, 2019 Bernard et. al., 2019; Sugandi \& Akbar, 2019) .

Dalam silabus pembelajaran matematika kurikulum 2013 revisi 2018 salah satu materi pelajaran matematika yang wajib dikuasai oleh siswa SMP kelas VII (tujuh) yaitu materi Bilangan Bulat dan Pecahan dimana salahsatunya ada pembahasan tentang KPK (kelipatan persekutuan terkecil) dan FPB (faktor persekutuan terbesar).

Menurut penelitian Rojabiah \& Setiawan (2019) minat belajar merupakan suatu kegiatan yang dilakukan oleh seseorang dalam proses pembelajaran secara tetap dengan perasaan senang tanpa adanya paksaan dari orang lain. Maka dari itu minat belajar siswa harus dilakukan tanpa adanya suatu hal yang 
dipaksakan, ketika siswa memiliki kerertarikan dalam sesuatu hal pasti siswa tersebut akan menyukai pembelajaran yang sedang berlangsung tanpa harus diperintah oleh guru.

Seiring dengan kemajuan teknologi saat ini, dunia pendidikan pun harus mengikuti arah perkembangan kemajuan teknologi, salahsatunya dalam pembelajaran mata pelajaran Matematika dengan media ICT didalam kelas, pada kurikulum 2013 guru diwajibkan menggunakan pendekatan saintifik dengan alat bantu atau media berupa ICT, salahsatunya yaitu media ICT berbasis VBA excel. Penggunaan media ICT berbasis VBA excel memiliki fungsi untuk mempermudah guru dalam menyampaikan suatu materi, sehingga siswa akan lebih mudah memahami jika memakai media ICT berbasis VBA excel (Bernard, 2018; Rohaeti, 2019; Bernard et. al., 2019).

Berdasarkan hasil penelitian yang dilakukan oleh Romlah, Nugraha, Nurjanah, dan Setiawan (2019) menyatakan bahwa hasil penelitian motivasi belajar siswa SD menggunakan media ICT berbasis VBA excel pada materi garis bilangan secara keseluruhan tergolong sangat baik. Berdasarkan dari hasil latar belakang diatas, maka peneliti akan melakukan studi pendahuluan yang berjudul "Analisis Motivasi Siswa SMP Cokroaminoto pada materi KPK dan FPB menggunakan Media ICT berbasis VBA excel".

\section{METODE}

Penelitian ini bertujuan untuk menganalisis minat belajar siswa SMP Terpadu Cokroaminoto dengan menggunakan media ICT berbasis VBA Excel pada materi FPB dan KPK yang berpedoman pada indikator minat belajar siswa. Adapun subjek penelitian ini yaitu 20 siswa kelas VII SMP Terpadu Cokroaminoto. Peneltian ini dilaksanakan pada akhir semester ganjil tahun ajaran 2019-2020. Pengumpulan data dalam penelitian ini menggunakan angket minat belajar. Angket minat belajar terdiri dari 20 pertanyaan dengan 5 indikator yang ada kaitannya dengan media ICT berbasis VBA Excel dan disediakan 4 pilihan jawaban siswa yaitu sangat setuju (SS), setuju (S), tidak setuju (TS) dan sangat tidak setuju (STS).Setelah pemberian angket peneliti memperoleh data minat belajar pada siswa kelas VII SMP Terpadu Cokroaminoto. Kemudian diolah secara menyeluruh agar memperoleh hasil data yang diinginkan dan baik.

\section{HASIL}

Angket minat belajar siswa yang terdiri dari 5 indikator. Angkettersebut memiliki empat pilihan jawaban yaitu sangat setuju (S), setuju (S), tidak setuju (TS), dan sangat tidak setuju (STS). Angket diberikan kepada 20 orang siswa di kelas VII SMP Terpadu Cokroaminoto. Pengolahan dan analisis dilakukan dengan presentase siswa pada setiap indikator minat belajar. 


\section{Tabel 1.}

Persentase Angket Minat Belajar Siswa

\begin{tabular}{|c|l|c|}
\hline No & \multicolumn{1}{|c|}{ Pernyataan } & Persentase \\
\hline A. & Indikator : Perasaan Senang & $74,1 \%$ \\
\hline B & Indikator : Ketertarikan Siswa & $74,5 \%$ \\
\hline C & Indikator : Keterlibatan Siswa & $72,8 \%$ \\
\hline D & Indikator : Rajin Dalam Belajar dan Rajin Mengerjakan Tugas Matematika & $66,7 \%$ \\
\hline E & Indikator : Tekun dan Disiplin dalam Belajar dan Memiliki Jadwal Pelajaran & $73,7 \%$ \\
\hline \multicolumn{2}{|c|}{ rata-rata } & $72,36 \%$ \\
\hline
\end{tabular}

Berdasarkan hasil presentase diatas terlihat bahwa pembelajaran pada materi FPB dan KPK dengan menggunakan media ICT berbasis VBA Excel terhadap minat belajar siswa kelas VII SMP Terpadu Cokroaminoto. Pada pernyataan soal no 1 yang memiliki 4 pernyataan, bernilai 2 positif dan 2 negatif dengan indikator perasaan senang mencapai 74,1 .Siswa tersebut merasa senang dan memahami dalam pembelajaran matematika dalam materi FPB dan KPK dengan menggunakan ICT berbasis VBA Excel. Sehingga dapat disimpulkan bahwa siswa merasa senang dalam belajar matematika dengan menggunakan media ICT berbasis VBA Excel (Sangat Baik).

Pernyataan kedua dengan indikator ketertarikan siswa yang memiliki 5 pernyataan bernilai 2 positif dan 3 negatif mencapai 74,5\%. Siswa tersebut merasa tertarik dan bersemangat dalam pembelajaran matematika dalam materi FPB dan KPK dengan menggunakan meida ICT berbasis VBA Excel. Sehingga dapat disimpulkan bahwa ketertarikan siswa dalam belajar matematika dengan menggunakan media ICT berbasis VBA Excel (Sangat Baik).

Pernyataan ketiga dengan indikator keterlibatan siswa yang memiliki 4 pernyataan bernilai 2 positif dan 2 negatif mencapai $72,8 \%$. Siswa tersebut berani mengemukakan pendapat, bersemangat dalam mengerjakan soal-soal dan merasa terlibat dalam pembelajaran matematika dalam materi FPB dan KPK dengan menggunakan media ICT berbasis VBA Excel. Sehingga dapat disimpulkan bahwa ketertarikan siswa dalam belajar matematika dengan menggunakan media ICT berbasis VBA Excel (Sangat Baik).

Pernyataan keempat dengan indikator rajin dalam belajar dan rajin mengerjakan tugas matematika yang memiliki 3 pernyataan bernilai 1 positif dan 2 negatif mencapai $66,7 \%$. Siswa tersebut enggan mengerjakan soal yang rumit dan lebih memilih soal yang sederhana dalam pembelajaran matematika dalam materi FPB dan KPK dengan menggunakan media ICT berbasis VBA Excel. Sehingga dapat disimpulkan bahwa siswa rajin dalam belajar dan rajin mengerjakan tugas matematikadalam belajar matematika dengan menggunakan media ICT berbasis VBA Excel (Baik). 
Pernyataan kelima dengan indikator tekun dan disiplin dalam belajar dan memiliki jadwal pelajaran yang memiliki 4 pernyataan bernilai 2 positif dan 2 negatif mencapai 73,7 \%. Siswa tersebut tetap berusaha menyelesaikan soal yang sulit meski dengan waktu yang lama dan memenuhi jadwal belajar yang telah tersusun dalam pembelajaran matematika dalam materi FPB dan KPK dengan menggunakan media ICT berbasis VBA Excel. Sehingga dapat disimpulkan bahwa siswa tekun dan disiplin dalam belajar dan memiliki jadwal pelajaran dalam belajar matematika dengan menggunakan media ICT berbasis VBA Excel (Sangat Baik) (Rahayu, 2019; Bernard, et. al, 2019).

Berdasarkan hasil data yang diperoleh dari siswa berupa angket dengan 20 pernyataan dan 5 indikator dapat disimpulkan bahwa dengan menggunakan media ICT berbasis VBA Excel pada materi KPK dan FPB kelas VII SMP Terpadu Cokroaminoto mempengaruhi minat belajar siswa dalam pembelajaran yang sedang beralangsung. Sejalan dengan hasil penelitian Bernard \& Chotimah (2018) bahwa pembelajaran dengan pendekatan Open-Ended menggunkan VBA Powerpoint lebih baik dibandingkan dengan kelas yang menggunakan pembelajran biasa. Rohaeti, Bernard \& Novtiar (2019) bahwa terdapat pengaruh media pembelajaran VBA Powerpoint dan Excel dalam meningkatkan kemampuan penalaran siswa dibandingkan dengan ssebelum menggunakan media. Romlah, Nugraha, Nurjanah \& Setiawan (2019) bahwa dari rata-rata skor keseluruhan soal dari semua indikator, siswa termasuk ke dalam kriteria sangat baik yaitu $88,21 \%$.

\section{KESIMPULAN}

Berdasarkan hasil dan pembahasan yang telah disajikan, bahwa dengan adanya minat belajar siswa pada materi KPK dan FPB mempengaruhi penggunaan media ICT berbasis VBA Excel pada siswa kelas VII SMP Terpadu Cokroaminoto. Dan terlihat dari hasil tabel minat belajar siswa paling tinggi yaitu pada indikator ketertarikan siswa, dimana siswa tertarik dengan menggunakan media ICT berbasis VBA Excel dengan persentase 72,36\%.

\section{DAFTAR PUSTAKA}

Akbar, P., Hamid, A., Bernard, M., \& Sugandi, A. I. (2018). Analisis kemampuan pemecahan masalah dan disposisi matematik siswa kelas xi sma putra juang dalam materi peluang. Jurnal Cendekia: Jurnal Pendidikan Matematika, 2(1), 144-153.

Al Ayyubi, I. I., Nudin, E., \& Bernard, M. (2018). Pengaruh Pembelajaran Berbasis Masalah terhadap Kemampuan Pemecahan Masalah Matematis Siswa SMA.JPMI (Jurnal Pembelajaran Matematika Inovatif), 1(3), 355-360.

Bernard, M., Akbar, P., Ansori, A., \& Filiestianto, G. (2019, October). Improve the ability of understanding mathematics and confidence of elementary school students with a contextual approach using VBA learning media for Microsoft Excel. In Journal of Physics: Conference Series (Vol. 1318, No. 1, p. 012035). IOP Publishing. 
Bernard, M., \& Chotimah, S. (2018). Improve student mathematical reasoning ability with open-ended approach using VBA for powerpoint. AIP Conference Proceedings, 2014(September). https://doi.org/10.1063/1.5054417.

Bernard, M. (2018). Meningkatkan Kemampuan Berpikir Kreatif Mahasiswa Matematik Melalui Pendekatan Problem Posing Berbantuan Visual Basic Application For Microsoft Excel. JPMI (Jurnal Pembelajaran Matematika Inovatif), 1(1), 69-78.

Bernard, M., \& Senjayawati, E. (2019). Developing the Students' Ability in Understanding Mathematics and Self-confidence with VBA for Excel. JRAMathEdu (Journal of Research and Advances in Mathematics Education), 1(1), 45-56.

Bernard, M., Sunaryo, A., Tusdia, H., Hendriani, E., Suhayi, A., Parida, M., ... \& Rolina, R. (2019, October). Enhance Learning Independence and Self Ability of Exceptional Children Through Developing Learning Media VBA for Excel Games. In Journal of Physics: Conference Series (Vol. 1315, No. 1, p. 012037). IOP Publishing.

Bernard, M., Sumarna, A., Rolina, R., \& Akbar, P. (2019, October). Development of high school student work sheets using VBA for microsoft word trigonometry materials. In Journal of Physics: Conference Series (Vol. 1315, No. 1, p. 012031). IOP Publishing.

Ernawati., Nurhayati, L,. \& Setiawan, W. (2019). “Analisis Minat Belajar Matematika Siswa SMA Pada Materi Program Linier Berbantuan Aplikasi Geogebra”. Journal on Education. Vol. 02 No. 01. Hal 1-8.

Haerini, R., Fauzan, G. A., \& Bernard, M. (2019). Penerapan Model Pembelajaran Reciprocal Teaching untuk Meningkatkan Minat Belajar Siswa SMP di Era Teknologi. JPMI (Jurnal Pembelajaran Matematika Inovatif), 2(5), 229-236.

Hidayat, F., Akbar, P., \& Bernard, M. (2019). Analisis Kemampuan Berfikir Kritis Matematik Serta Kemandiriaan Belajar Siswa Smp Terhadap Materi Spldv. Journal on Education, 1(2), 515-523.

Insani, S. U., \& Akbar, P. (2019, October). Development of Open-Ended Based Mathematics Problem to Measure High-Level Thinking Ability. In Journal of Physics: Conference Series (Vol. 1315, No. 1, p. 012047). IOP Publishing.

Rahayu, G., Arga, H., Altaftazani, D., \& Bernard, M. (2019, November). Effect of VBA Learning Media to Improve Students Decision Making Skill of Elementary School. In 2019 Ahmad Dahlan International Conference Series on Education \& Learning, Social Science \& Humanities (ADICSELSSH 2019). Atlantis Press.

Rohaeti, E. E., Bernard, M., \& Novtiar, C. (2019). Pengembangan Media Visual Basic Application untuk Meningkatkan Kemampuan Penalaran Siswa SMP dengan Pendekatan Open-Ended. 3(2), 95-108. 
Rohaeti, E. E., Bernard, M., \& Primandhika, R. B. (2019). Developing Interactive Learning Media for School Level Mathematics through Open-Ended Approach Aided by Visual Basic Application for Excel. Journal on Mathematics Education, 10(1), 59-68.

Romlah, S., Nugraha, N., Nurjanah, S., \& Setiawan, W. (2019). "Analisis Motivasi Belajar Siswa SD Albarokah 448 Bandung dengan Menggunakan Media ICT Berbasis For VBA Excel pada Mater Garis Bilangan”. Jurnal Cendekia: Jurnal Pendidikan Matematika, 3 (1), 209-219.

Sugandi, A. I., \& Akbar, P. (2019). Efektivitas Penerapan Strategi React Terhadap Kemampuan Koneksi Matematis dan Self-Efficacy Siswa SMP. Jurnal Cendekia: Jurnal Pendidikan Matematika, 3(2), 431-436 